\title{
Склярук К.B.
}

\section{Формирование эстетических чувств и предпочтений} у младших школьников во внеурочной деятельности

\author{
Sklyaruk K.V. \\ The formation of aesthetic feelings, and preferences among \\ primary school children in extracurricular activities
}

В данной статье описана актуальность и решение проблемы формирования эстетических чувств и предпочтений у младших школьников во внеурочной деятельности

Ключевые слова: эстетические предпочтения и чувства, книга, исследование

\section{Склярук Катерина Владимировна}

Студент

Педагогический колледж № 15

г. Москва, ул. Бирюлевская, 28
This article describes the relevance and solution of the problem offormation of aesthetic feelings, and preferences among primary school children in extracurricular activities

Key words: aesthetic preferences and feelings, book, study

\author{
Sklyaruk Katerina Vladimirovna \\ Student \\ Pedagogical college № 15 \\ Moscow, Biryulevskaya st., 28
}

Научный руководитель: Литвиненко Л.П.

Актуальность проводимого исследования заключается в том, что необходимо наглядно определять уровень сформированности эстетической культуры современных школьников, так как эстетическое воспитание занимает ведущее место в системе образования. Наличие эстетического воспитания является показателем культурного уровня страны и общества в целом.

Освоение мира осуществляется непременно в эстетической форме. Человеческая деятельность протекает на основе определенных эстетических идей, представлений, установок. Эстетика входит в труд, быт, в промышленное производство, формируя в человеке созидательное начало и способность воспринимать красоту. И для этого с самых ранних лет надо помогать ребенку постигать прекрасное. В начале красивая игрушка, милая песенка, первый легкий стишок под красивой картинкой... А потом уже книги посерьезнее, посложнее, и убранство комнаты, и платьице для куклы, и хорошая музыка, к которой следует прислушиваться, и стихи с последующим раздумчивым разговором о них, и зеленое 
раздолье полей, манящее в даль во время летней прогулки, и хороший спектакль в детском театре, и разделенное с ребенком волнение, которое породил интересный фильм...

Книга давно уже стала одним из самых деятельных помощников семьи по воспитанию эстетического вкуса у младшего поколения. Хорошая книга становится первым и верным другом детства миллионов ребят. Можно с уверенностью сказать, что нет на просторах нашей Родины такого дома, где не нашлось бы детской книжки.

В младшем школьном возрасте успешно происходит и художественно-эстетическое развитие детей. Дети обычно очень интересуются рисованием, лепкой, пением, музыкой; на основе соответствующей деятельности и восприятия художественных произведений (стихотворений, музыки, картин, скульптур) у них формируются эстетические чувства.

Именно поэтому необходимо в начальных классах формировать у учащихся эстетические предпочтения и чувства.

Самой плодотворной, на наш взгляд, деятельностью для учителя, которая позволяет формировать эстетические представления и чувства является внеурочная деятельность, позволяющая целесообразно осуществлять решение задач воспитания и социализации.

При помощи определенных форм организации внеурочной и внешкольной работы, примерных тематик занятий и методик проведения игр можно достичь планируемого результата, которое заключается в формировании представлений об эстетических идеалах и ценностях у детей младшего школьного возраста.

Итак, проблема исследования необходимость формирования эстетических чувств и предпочтений у младших школьников.

Цель исследования: определить педагогические условия для формирования эстетических чувств и предпочтений младших школьников.

Объект исследования: эстетические чувства и предпочтения младших школьников.

Предмет исследования: формирование эстетических чувств и предпочтений у младших школьников как элемента духовно-нравственного воспитания.

В соответствии с целью, объектов и предметом поставлены следующие задачи исследования:

- проанализировать теоретические основы формирования эстетических чувств и предпочтений младших школьников;

- проанализировать возрастные особенности младших школьников;

- разработать методические рекомендации по формированию эстетических чувств и предпочтений в области духовно-нравственного воспитания во внеурочной деятельности.

Метод: изучение психолого-педагогической литературы по проблеме исследования. 
2. Выготский Л.С. Нравственное воспитание. Педагогическая психология. М. 1991.

3. Григорьев Д.В., Степанов П.В. Внеурочная деятельность школьников. М.: Просвещение, 2014.

4. Ожегов С.И. Словарь русского языка. М.: Оникс, 2008. 1200 с.

5. Эстетическое воспитание в семье. М.: Искусство, 1963.

(C) 2016, Склярук К.В.

Формирование эстетических чувств и предпочтений у младших школьников во внеурочной деятельности
(C) 2016, Sklyaruk K.V.

The formation of aesthetic feelings, and preferences among primary school children in extracurricular activities 